\title{
Ефективност на мукозосъхраняващите техники за редукция на обема на долните конхи - RFTR vs MAIT. Метаанализ на налични литературни данни
}

\author{
Надя Сербезова
}

Рецензент - проф. Румен Бенчев

Рецензия от проф. Румен Бенчев д.м.н., председател на БНСОРЛХГШ.

Предложената ми за рецензия статия представлява метаанализ на изследвания за функционалността на два оперативни метода за лечение на хипертрофията на долните носни конхи. Хипертрофичният ринит е честа причина за затруднено носно дишане и е обект на множество хирургични интервенции. В миналото операциите на долните носни конхи не отчитаха необходимостта от запазване на функцията на носната лигавица, поради което те бяха свързани с редица усложнения като атрофичен ринит, чести епистаксиси и дори empty nose syndrom. Направеният метаанализ на двете мукосъхраняващи оперативни техники ясно посочва тенденциите, към които трябва да се стремим - запазване на функциите на носната лигавица чрез хирургично въздействие върху подлигавичното пространство. В този смисъл статията на д-р Сербезова безспорно допринася за популяризирането на функционалната хирургия на носа в България, поради което напълно я подкрепям и считам, че тя може да бъде отпечатана в специализирано медицинско списание.

София 15.02.2013 г.

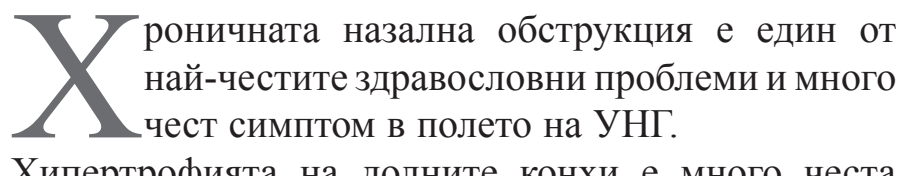
Хипертрофията на долните конхи е много честа причина за обструкция и може да се дължи на:

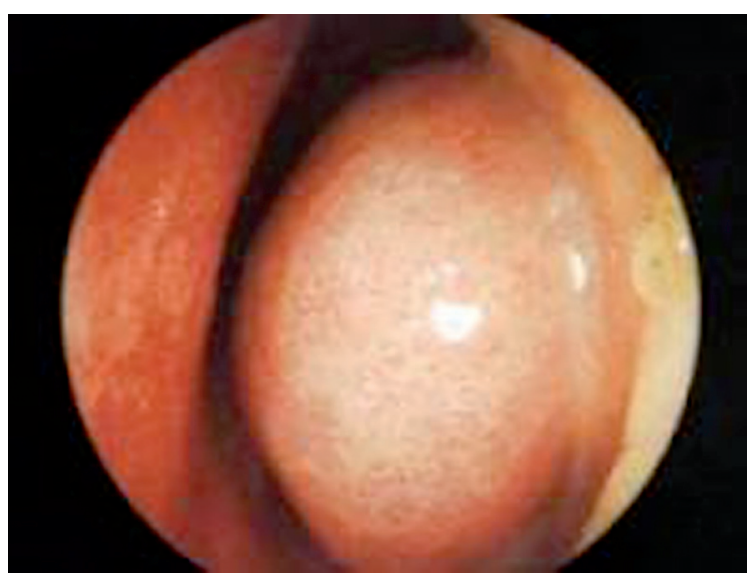

- хроничен ринит

- алергичен ринит

- псевдоалергия;

- неалергичен ринит с еозинофилен синдром;

- медикаментозен ринит;

- едностранна хипертрофия на долната конха при девиация на септума.

Локалната медикаментозна терапия възстановява комфорта на назалното дишане, но често е с време- 
нен ефект. Обструкцията само леко се подобрява, което води при много пациенти до повишен прием на локални деконгестанти с висок риск от ятрогенни ефекти.

Хирургичното лечение се прилага при неуспех от медикаментозното лечение. Ако медикаментозното лечение е каузално (например при алергичен ринит), то обаче се продължава и след хирургичната намеса.

Множество хирургични техники за намаляване на обема на мукозната и понякога костна тъкан на долната конха се прилагат понастоящем. Повечето от тези техники дават задоволителни резултати за по-дълъг или по-къс период от време, но страничните ефекти след подобни процедури са чести: следоперативно кървене, крусти, болка, хипосмия, синехии.

Големият брой хирургични техники показват липсата на консенсус по отношение на оптималната техника.

В оценяването на различните методи на редукция на конхите преди всичко трябва да се вземе под внимание запазването на функцията при всеки от тях.

Хойзинг и сьтрудници при оценката на 13 хирургични техники, използвани през последните 130 години за лечение на хипертрофия на долната конха, заключават, че методът на избор трябва да бъде редукцията на долната конха с оптимално запазване на функцията. (1)

\section{Основните функции на конхата са:}

- допринася за инспираторното носно съпротивление, необходимо за нормалното дишане

- допринася за регулирането на въздушния поток

- играе важна роля в овлажняването, затоплянето и очистването на въздуха

- мукоцилиарната функция е важен защитен механизъм за протекция на респираторната система от бактерии и чужди тела.

Носната мукоцилиарна функция се нарушава при повечето от хирургичните методи за редукция на долната конха.

Целите на всяко хирургично лечение на хипертрофията на долната конха трябва да са едновременно премахване на оплакванията със запазване на функцията и оптимално намаляване на обема на конхата. Създаването на по-широк носен ход не означава непременно по-добра функция на носа.
Целта на проучването е да се сравни ефикасността на двете най-често ползвани днес мукозосъхраняващи микроинвазивни хирургични техники за лечение на хипертрофията на долната конха при запазване на функцията ѝ:

- субмукозната радиочестотна аблация (RFTR) - монополярна и биполярна

- субмукозната резекция с микродебридер (MAIT)

Микродебридерът представлява куха сонда с осцилиращ резец на работния край и вакуумно изсмукване на изрязаните материи и телесните течности в работното поле. Различни по размер и форма остриета дават голям избор от възможности за оператора. При него най-честите недостатъци на стандартната резекция, като прекалено ексцесивната резекция, следоперативното кървене и крустите, са силно намалени и ограничени до постоперативно кървене в под $2 \%$ от пациентите.

Радиочестотната аблачия с моно или биполярен активен електрод използва радиочестотна енергия, загряваща околните тъкани, което води до субмукозна некроза. Ограничената зона на некроза се замества с течение на времето с фибробласти. Контракцията на раната при фиброзата намалява субмукозния обем, съответно и обструкцията на носа, без да се уврежда надлежащата мукоза. Радиочестотната аблация е контраиндицирана при пациенти с пейсмейкър или други имплантирани електронни устройства освен ако същите не могат да бъдат временно изключени.

Типът на проучването е метаанализ на налични литературни данни за насочени клинични проучвания от последните 7 години. Търсени са проучвания със сходни методи на работа и контрол на резултатите.

За целта са систематизирани резултатите от проучвания на множество автори относно ефекта на двата метода при хирургичното лечение на хипертрофия на конхите. Обобщени са събраните от тях субективни и обективни данни за оценка на дълготрайните ефекти от лечението.

Обхват на проучването: Включва клинични проучвания, обхващащи ранния постоперативен период (7дни и 1-ви месец), късния постоперативен период (3 и 6 месеца) и дълготрайните ефекти и удовлетворение на пациентите (1 до 3 години следоперативно). 
- При едно от подбраните клинични проучвания целевата група се състои от 30 симптоматични пациенти, които са подложени едновременно на RFTR и MAIT върху противоположните страни на носа. (2)

- При всички проучвания са приложени както субективни методи за оценка - аналогово степенуване на обструкцията (VAS), така и обективни изследвания - акустична ринометрия (ARM) пред- и постоперативно.

- Съхраняването на функционалността на носната лигавица се оценява най-често със STT (saharin transport time) и цилиарна честота - CBF.

- Нуждата от ревизия се определя най-често между 6 и 12 месец следоперативно.

Оценка на симптомите: При всички разгледани проучвания са били приложени пред- и следоперативно различни субективни и обективни методи за оценка на ефекта от прилагането на оперативните техники.

- субективни методи:

○ аналогово степенуване на обструкцията (visual analog scale - VAS)

○ субективна оценка на други симптоми като постоперативна ринорея, хипосмия, главоболие и хьркане

- обективни изследвания:

- акустична ринометрия (acoustic rhinometry - ARM)

○ функция на носния епител (захаринов тест и цилиарна честота)

Акустичната ринометрия е провеждана в деня преди операцията и е повтаряна през различни периоди следоперативно. Най-често е оценяван обхватьт от 0 до $5 \mathrm{~cm}$, тъй като той включва функционалната носна клапа и по-голямата част от септалната и латералната еректилна тъкан.

Функиията на носния епител е оценявана преди следоперативно ин виво чрез захаринов тест и ин витро чрез изследване на цилиарната честота.

Захаринов тест - STT е измерено след поставяне на 15 мг 2\% натриева сол на захарин със $1 \%$ индиготин на пода на носа на нивото на главата на долната конха. Пациентьт е помолен да преглъща на всеки 30 сек. Незабавно след като усети вкуса на захарин, тестът се спира и трансферьт се потвърждава чрез директно наблю- даване на синьото оцветяване от индиготин на фарингеалната стена.

Цилиарна честота - CBF. Повърхностни клетки от носната мукоза са взети с четкова биопсия от средната част на долната конха под локална анестезия. Клетките са незабавно поставени в тъканна култура и цилиарната честота се измерва стробоскопски на светлинен микроскоп при стайна температура и се оценява в херци $(\mathrm{Hz})$.

Хирургичните процедури при всички проучвания са направени със седация и локална анестезия или в хода на друга процедура, изискваща прилагането на обща анестезия.

При RFTR максималните стойности са били ограничени между 60 и 90 градуса, 2-8 вата, $300-350$ Ј и $2-2,5$ мин. Коагулира се в няколко зони - най-често две в предната и една в средната част на конхата. При радиочестотната редукция не се наблюдават ерозия на мукозата, кървене или образуване на крусти. Най-честите оплакване са болка, секреция и запушване на носа незабавно след процедурата, които прогресивно намаляват в следващите няколко дни.

При МАIT част от субмукозната тъкан и понякога долната част на костта се премахват с 3000 оборота осцилация в посока отпред назад. Хемостаза се постига при пряк оглед с електрокаутеризация. Следоперативно за контрол на минимално кървене се ползва хемостатична гъба за 48 часа. При микродебридерната техника не се наблюдава неконтролирано крьвотечение, няма загуба на мукоза, рядко се съобщава за синехии. Минимално кървене в ранния постоперативен период се наблюдава също рядко и се овладява с хемостатични гъби.

При едно от проучванията двата метода са приложени едновременно върху двете ноздри на един и същ пациент. (2)

Статистическият анализ не показва сигнификантна разлика между усложненията при всяка процедура.

Оценка на нуждата от ревизия: Нуждата от ревизия във всяка група е преценена между 6 и 12 месец следоперативно. Тя е оценена в зависимост от субективните оплаквания на пациента и обективните находки. Оценени като нуждаещи се от ревизия са:

- пациенти, чиито симптоми са намалели само частично

- пациенти, чиито симптоми не са подобрени изобщо 
- всички пациенти с лоши резултати на VAS и

тивните измервания. ARM измерванията, сравнени с предопера-

Наблюдения на изследователските екипи:

\begin{tabular}{|c|c|c|c|c|c|c|c|}
\hline $\begin{array}{c}\text { Проучване и } \\
\text { бр. лица }\end{array}$ & $\begin{array}{l}\text { Техника } \\
\text { бр. лица }\end{array}$ & 7 ден & 1 месец & 3 месец & 6 месец & 1 година & 3 години \\
\hline \multirow{2}{*}{$\begin{array}{l}\text { Prof. C. Cingi et al. } \\
\text { (3) } 268\end{array}$} & RFTR - 144 & + & + & + & NA & NA & NA \\
\hline & MAIT - 124 & $+/-$ & + & + & NA & NA & NA \\
\hline \multirow{2}{*}{ Kizilkaya et al. 30* } & RFTR - 30 & NA & NA & + & + & + & NA \\
\hline & MAIT - 30 & NA & NA & + & + & ++ & NA \\
\hline \multirow{2}{*}{$\begin{array}{l}\text { Lee JY, Lee JD } \\
\text { et al. (4) } 60\end{array}$} & RFTR - 30 & NA & NA & + & + & ++ & NA \\
\hline & MAIT - 30 & NA & NA & + & ++ & +++ & NA \\
\hline \multirow{2}{*}{$\begin{array}{l}\text { Liu CM, Tan CD } \\
\text { et al (5) } 120\end{array}$} & RFTR - 60 & NA & NA & + & + & + & + \\
\hline & MAIT - 60 & NA & NA & + & + & ++ & +++ \\
\hline
\end{tabular}

* При това изследване специфично е прилагането на двете микроинвазивни техники едновременно при един и същ пациент. NA-няма данни, $0,+,++,+++-$ степен на комфорт

- Захариновият тест - STT и цилиарната честота - CBF не показват сигнификантни вариации следоперативно в сравнение с вътрегруповите измервания.

- Значимо подобрение във VAS/ARM резултатите е постигнато и след двете процедури. Двата параметьра не се различават значимо до 6-ия месец следоперативно. Разлика има само в най-ранните етапи, дължаща се на следоперативния едем.

- Нуждата от ревизия и при двата метода не се различава сигнификантно към края на първата година постоперативно.

- Разлика в обективните резултати и удовлетворението на пациентите започва да се наблюдава след 6-я месец постоперативно до към края на първата година.

\section{Субективна промяна на симптомите}

При микродебридерната техника субективните симптоми леко се влошават по време на първите 3-4 дни следоперативно и започват да се подобряват след 7-я ден.

При радиочестотната аблация обструкцията се подобрява от 3 ден след лечението.

И при двете групи сигнификантно подобряване на VAS се наблюдава на 3-ия месец и се задържа на 6-ия.

Обективна оценка на симптомите

Акустичната ринометрия - ARM не показва сигнификантна разлика между двете групи на 3 и 6 месец.

Епителната функция - STT и CBF са направени и за двете носни половини, като разликите между тях не са статистически значими на 3 и 6 месец.

\section{Обобъщение}

- Идентични резултати в обективните и субективните параметри се наблюдават и при двете техники. От друга страна обаче задържането на ефекта след 3 години е значително подобро при MAIT. (5)

- Разликата в обективните показатели и субективните усещания на пациентите при двата метода започва да се откроява към края на първата година.

- MAIT е по-ефективна в намаляването на носния обем. (6)

- RFTR е по-лесна и по-малко инвазивна процедура.

- Мукоцилиарната функция се запазва и при двете техники, без статистическа значима разлика между двата метода.

- При другите хирургически техники не може да се запази носният епител и неговата функция, т.е. мукоцилиарният клирънс до такава степен. 


\section{Изводи}

- Идеалната хирургия на конхата трябва да бъде ограничена до еректилната субмукозна тькан и костта.

- Редукцията на костта създава повече пространство, а хирургията на субмукозата минимизира отока на долните конхи.

- Запазването на мукозата подобрява шансовете за запазване на функцията на долната конха.

- MAIT е метод на избор при хипертрофия на долната конха за сметка на костната ѝ част.

\section{Библиография}

1. Huizing EH, Hol MK, Treatment of inferior turbinate pathology: a review and critical evaluation of the different techniques. Rhinology 2000; 38: 157-66.

2. Kizilkaya Z, Ceylan K, Emir H, et al. Comparison of radio-frequency tissue volume reduction and submucosal resection with microdebrider in inferior turbinate hypertrophy. Otolaryngol Head Neck Surg 2008; 138: 176-81.

3. C.Cingi, B.Ure, H.Cakli, and E.Ozudogru. Microdebrider-assisted versus radiofrequency-assisted inferior turbinoplasty: a prospective study with objective and subjective outcome measures. Pubmed November 2009; 19, 20
- Поради превеса на удовлетворението на пациентите и запазване на обективните резултати в дълготраен аспект, наблюдаван в анализираните проучвания, резекцията с микродебридер - MAIT е за предпочитане.

- Въпреки всичко изборът на мукозосъхраняващ метод се определя индивидуално за всеки пациент, често зависи от предпочитанията на оператора, достьпността на метода, начална инвестиция и текущи разходи за поддрьжка и консумативи на апаратурата.

4. Lee JY, Lee JD. Comparative study on the long-term effectiveness between coblation and microdebrider-assisted partial turbinoplasty. Laryngoscope 2006; 116: 729-34.

5. Liu CM, Tan CD, Lee FP, Lin KN, Huang HM. Microdebrider-assisted versus radiofrequency-assisted inferior turbinoplasty. Laryngoscope. Feb 2009; 119(2): 414-8.

6. Gindros G, Kantas I, Balatsouras DG, Kaidoglou A, Kandiloros D. Comparison of ultrasound turbinate reduction, radiofrequency tissue ablation and submucosal cauterization in inferior turbinate hypertrophy. Eur Arch Otorhinolaryngol. Nov 2010; 267(11): 1727-33. 